\title{
ANALISA DAYA LISTRIK OPTIMUM MODEL SCREW TURBINE 2 BLADE SEBAGAI PENGGERAK GENERATOR LISTRIK
}

\author{
JAMALUDIN \\ Program Studi Teknik Mesin, Fakultas Teknik \\ Universitas Muhammadiyah Tangerang \\ Jl. Perintis Kemerdekaan I/33, Cikokol, Kota Tangerang \\ Email: jamaludinpermana14@yahoo.com
}

\begin{abstract}
ABSTRAK
Akibat dari krisis energi yang terjadi di dunia, terutama akibat keterbatasan bahan bakar minyak yang mengakibatkan mengurangi ketersediaan listrik, maka diadakanlah penelitian-penelitian untuk membuat Pusat Tenaga Listrik Mikrohidro (PLTMH) dengan memanfaatkan bermacam tipe turbin air. Salah satu dari tipe turbin yang sangat berpotensi untuk pembangkit listrik mikrohidro pada sungai-sungai di Indonesia adalah Turbin Screw (Archimedean Turbine). Hasil penelitian dengan menggunakan rancangan rangkaian listrik model Turbin Screw dan daya listrik yang dihasilkan pada pengujian berbeban, secara umum denan menggunakan model turbin ulir dengan jarak pitch 1,2Ro memberikan daya yang lebih tinggi dibandingkan dengan model turbin ulir dengan jarak pitch 2Ro dengan daya generator sebesar 4,68 watt dan efisiensi sebesar $19,56194 \%$. Pitch $1,2 \mathrm{R}_{0}$ menunjukkan daya tertinggi sebesar 6,58 watt pada sudut kemiringan poros $30^{\circ}$ dan efisiensi tertinggi pada pitch $1,2 \mathrm{R}_{0}$ dengan sudut kemiringan poros $30^{\circ}$ yaitu sebesar $84 \%$ tanpa pengujian beban. Efisiensi generator adalah hasil pembagian dari daya generator dan daya turbin yang didapat dari hasil pengukuran. Pada pengujian model turbin ulir, semakin besar pembebanan lampu yang diberikan, maka putaran generator juga akan semakin berkurang
\end{abstract}

Kata Kunci: Turbine Screw, Daya Listrik, Rangkaian Listrik, Perancangan.

\section{PENDAHULUAN}

Pembangunan PLTA berkapasitas kecil akhir-akhir ini menjadi perhatian dunia termasuk negara-negara maju. Pembagian PLTA dengan kapasitas kecil pada umumnya adalah sebagai berikut:

a) PLTA Mikro $<100 \mathrm{~kW}$

b) PLTA Mini $100-999 \mathrm{~kW}$

c) PLTA Kecil 1000-10.000 kW

Salah satu sebab bagi negara-negara maju memperhatikan pembangunan PLTA berkapasitas kecil ini adalah harga minyak OPEC yang terus meningkat pada waktu yang lalu, disamping bertambahnya kebutuhan listrik. Sampai sekarang ini, pembangkitan listrik dengan tenaga air merupakan pembangkitan yang paling ekonomis, sehing- ga potensi tenaga air perlu dimanfaatkan. Di negara-negara maju pun potensi tenaga air Mikro/Mini belum dimanfaatkan, sedangkan untuk daerah-daerah terpencil pembangkitan listrik dengan PLTA Mikro/Mini masih lebih menguntungkan dibandingkan dengan menghubungkan daerah ini dengan hantaran tegangan tinggi dari sentral-sentral listrik yang besar. Di Indonesia sendiri salah satu program pemerintah adalah listrik masuk desa. Untuk desa terpencil di daerah pegunungan, pembangunan PLTA Mikro merupakan salah satu jawaban atas program pemerintah tersebut karena menghubungkan desa ini dengan hantaran tegangan tinggi tidaklah ekonomis.

Screw Turbin (Archimedean Screw) dalam hal ini salah satu alternatif pusat listrik 
tenaga mikrohidro yang sangat berpotensi untuk sungai-sungai di Indonesia. Jika ditinjau dari segi investasi, pembangunan pusat listrik tenaga mikrohidro hanya memerlukan biaya yang kecil. Hal inilah yang mendukung kami untuk merancang pembangkit listrik mikrohidro sebagai salah satu cara agar krisis energi listrik dapat dihindari dan aktivitas kehidupan dapat berjalan seperti biasa. Di lapangan pada umumnya tenaga air yang dapat diketahui hanya harga head dan debitnya saja, dimana di setiap tempat memiliki harga head dan debit yang berbeda-beda. Tujuan perancangan, pembuatan, dan pengujian screw turbin ini adalah agar daya listrik keluaran yang dihasilkan dapat semaksimal mungkin sehingga mampu memenuhi kebutuhan listrik di daerah tersebut. Dengan kemajuan teknik, tinggi $H=1-1,5 \mathrm{~m}$ dapat digunakan dan kapasitas screw turbin dapat dibuat $4-5 \mathrm{~kW}$.

Lokasi yang dipilih dalam penelitian ini adalah saluran irigasi di Kp. Kadu Kampeng RT. 007 RW. 003 Ds. Cimanuk Kec. Cimanuk Kabupaten Pandeglang, Banten kode pos: 42271. Screw turbin ini direncanakan akan dapat menghasilkan daya sebesar 80 Watt dimana screw turbin yang digunakan berjenis jarak pitch $\Lambda=2 R_{o}$ dan $1,2 \mathrm{R}_{\mathrm{o}}$ dengan menggunakan sebuah generator listrik sebagai pembangkit daya serta menggunakan sistem rangkaian listrik.

Selain perancangan, pembuatan dan pengujian screw turbin itu sendiri hal lain yang tidak kalah pentingnya adalah selalu menghitung daya yang dihasilkan screw turbin tersebut. Dalam penelitian ini, saya selaku peneliti akan membahas daya listrik optimum model screw turbin dengan jarak pitch $\Lambda=2 R_{o}$ dan $1,2 R_{o}$. Dimana daya ini dihasilkan generator listrik yang diputar oleh poros. Screw turbin memiliki kemiringan sudut yang bervariasi dimulai dari $25^{\circ}$ sampai $35^{\circ}$. Sehingga akan dipaparkan proses pembangkitan daya ini dimulai dari kemiringan $25^{\circ}$ hingga diperoleh hasil maksimum yang diinginkan.

\section{TINJAUAN PUSTAKA}

\section{a. Screw Turbine}

Screw turbine merupakan salah satu turbin yang sangat spesial karena dapat beroperasi pada daerah yang memiliki head yang sangat rendah. Pada penggunaannya Screw turbin ini posisi sudunya tergantung dari kondisi head yang ada di lapangan. Screw turbine bekerja pada head rendah dengan ketinggian air jatuh antara $1-15 \mathrm{~m}$. Sudut untuk penentuan head turbin berada antara $30^{\circ}-60^{\circ}$. Screw turbine terdiri dari dua tipe yaitu: Type Steel Trough dan Type Closed Compact Installation. Kedua tipe tersebut dapat dilihat pada Gambar 2.1 di bawah ini.

\section{b. Cara Kerja Screw Turbine}

Proses perubahan energi pada screw turbine hingga menjadi energi listrik yaitu dimana energi yang berasal dari energi potensial yang terdapat pada air dan perubahan tekanan yang terjadi pada sudu mengakibatkan sudu berputar dan memutar poros, sehingga terjadi perubahan energi kinetik juga energi tekanan menjadi energi mekanik. Selanjutnya daya dari poros ditransmisikan ke generator yang nantinya diubah menjadi energi listrik. Energi listrik yang dihasilkan oleh generator nantinya didistribusikan ke konsumen melalui inverter.

Blok diagram konversi energi ditunjukkan pada Gambar 1 di bawah ini.

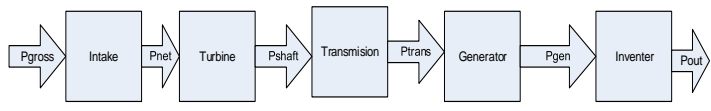

Gambar 1 Blok diagram konversi energi.

Adapun prinsip kerja dari screw turbin ini dimana tekanan dari air melalaui bilahbilah sudu turbin mengalami penurunan kecepatan air akibat adanya hambatan dari bilah-bilah sudu turbin, maka tekanan ini akan memutar turbin dan menggerakkan generator listrik dimana sebelumnya daya putaran poros ditransmisikan melalui gearbox.

Prinsip kerja dari screw turbine secara umum dapat dilihat pada gambar 2 dibawah ini. 


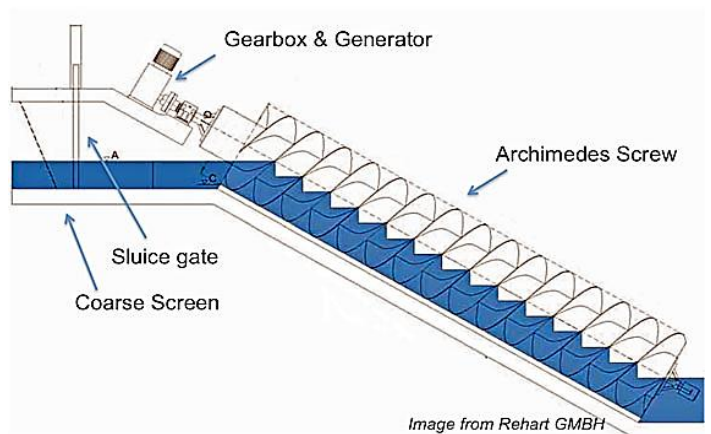

Gambar 2 Prinsip kerja screw turbin.

\section{c. Klasifikasi Kecepatan Air}

Karakteristik kecepatan air di sungai tidak jauh berbeda dengan karakteristik kecepatan air di suatu saluran. Karena aliran di sungai pada umumnya adalah turbulen seperti halnya aliran di saluran, maka debit aliran melalui saluran terbuka dapat dihitung dengan rumus berikut:

$\mathrm{Q}=\mathrm{A} \mathrm{V}$

$\left(\mathrm{m}^{3} / \mathrm{s}\right)$

Untuk garis-garis distribusi kecepatan (isovel) pada suatu alur sungai ditunjukkan pada Gambar 3 dibawah ini.

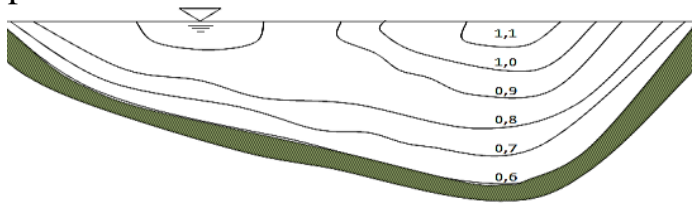

Gambar 3 Distribusi kecepatan (isovel) suatu penampang sungai alamiah.

Sumber:(Maryono, 2005)

Tabel 1 Perbandingan Vm / Vo, untuk menentukan besarnya kecepatan rata-rata.

\begin{tabular}{ll}
\multicolumn{1}{c}{ Jenis Material dasar Sungai } & $\begin{array}{c}\text { Vm / Vo, } \\
\text { mak }\end{array}$ \\
\hline $\begin{array}{l}\text { Batuan kricak halus sampai } \\
\text { menengah }\end{array}$ & 0,83 \\
$\begin{array}{l}\text { Batuan kricak besar kasar } \\
\text { Lempengan kasar }\end{array}$ & 0,71 \\
$\begin{array}{l}\text { Batuan kricak dengan rumput- } \\
\text { rumputan }\end{array}$ & $0,40-0,52$ \\
$\begin{array}{l}\text { Batuan kricak kasar dengan batu- } \\
\text { batu besar }\end{array}$ & $0,46-0,75$ \\
$\begin{array}{l}\text { Batuan kricak sangat besar } \\
\text { Lempung berpasir }\end{array}$ & $0,58-0,70$ \\
\end{tabular}

Kecepatan aliran melalui saluran terbuka dapat dihitung dengan beberapa rumus berikut:

$$
\begin{aligned}
& Q=V_{1} \cdot A_{1}=V_{2} \cdot A_{2} ; \quad V_{r}=\frac{Q}{A} \\
& V=C \sqrt{R I} \\
& C=k_{s t} \cdot R^{1 / 6} \\
& V=k_{s t} \cdot R^{2 / 3} \cdot I^{1 / 2} \\
& V=\frac{1}{n} \cdot R^{2 / 3} \cdot I^{1 / 2}
\end{aligned}
$$

Dimana:

$k_{s t}=\frac{1}{n}$

Koefisien Chezy dapat dinyatakan dengan koefisien Manning dengan persamaan:

$C=\frac{1}{n} R^{\frac{1}{6}}$

Dimana $\mathrm{n}$ adalah nilai koefisien Manning yang merupakan fungsi dari bahan dinding saluran. Pada umumnya tipe aliran melalui saluran terbuka adalah turbulen, karena kecepatan aliran dan kekasaran dinding relatif lebih besar. Aliran melalui saluran terbuka akan turbulen apabila bilangan Reynolds $\operatorname{Re} \geq 4000$, dan laminer apabila $\operatorname{Re} \leq 2000$.Untuk saluran melalui pipa pada gambar debit aliran dapat ditentukan dengan rumus:

$Q=A V=A \frac{1}{2} R^{\frac{2}{3}} I^{\frac{1}{2}}$

\section{d. Daya Generator}

Generator yang akan digunakan pada penelitian ini adalah Alternator dengan kecepatan putar $(\mathrm{rpm})$ yang disesuaikan dengan kecepatan putar turbin ( $\mathrm{rpm}$ ) yang akan diuji.

Adapun daya generator dapat dihitung dengan persamaan:

$P g=V_{L} \cdot I_{L} \cos \Phi$ (watt)

Dimana:

$$
\begin{array}{ll}
\mathrm{Pg} & =\text { daya generator }(\mathrm{W}) \\
\mathrm{V}_{\mathrm{L}} & =\text { tegangan }(\mathrm{V}) \\
\mathrm{I}_{\mathrm{L}} & =\text { arus }(\mathrm{A}) \\
\cos \Phi & =\text { faktor daya }
\end{array}
$$

\section{e. Kecepatan Putaran Turbin}

Semenjak generator dan turbin digabungkan, rata-rata kecepatan putar turbin sama dengan kecepatan putar generator, dinyatakan sebagai:

$N_{t}=\frac{60 f}{p}$. 
Dimana:

$\mathrm{N}_{\mathrm{t}}=$ kecepatan putaran (rpm)

$f \quad=$ frekwensi $(\mathrm{Hz})$

$p \quad=$ jumlah pasang kutub generator

Jadi kecepatan putaran turbin ditentukan oleh kecepatan putaran generator. Kecepatan spesifik dari turbin dinyatakan sebagai berikut:

$N_{S}=\frac{N t \sqrt{P}}{h^{5 / 4}}$

Dengan: $N_{S}=$ kecepatan spesifik (rpm)

\section{f. Energi dan Availabilitas}

Energi adalah sesuatu yang bersifat abstrak yang sukar dibuktikan tetapi dapat dirasakan adanya. Energi adalah kemampuan untuk melakukan kerja (energy is the capability for doing work).

Availabilitas adalah kemampuan sistem untuk menghasilkan kerja yang berguna (availability is an ability of a system to produce a useful effect). Jadi keberadaan availabilitas lebih realistis, mudah dibuat dan dapat dirasakan kegunaannya. Menurut hukum Termodinamika Pertama, energi bersifat kekal. Energi tidak dapat diciptakan dan tidak dapat dimusnahkan, tetapi dapat dikonversi dari satu bentuk energi ke bentuk energi yang lain. Sedang availabilitas adalah kemampuan suatu sistem untuk menghasilkan suatu pengaruh yang berguna bagi kebutuhan manusia secara positif.

\section{g. Metode Penelitian}

Dalam bab ini akan dibahas mengenai prosedur penelitian dimulai dari perancangan, pembuatan alat, serta pengujian alat, sehingga didapatkan analisa hasil yang akan digunakan sebagai kesimpulan dari daya listrik optimum model Screw Turbine 2 blade. Pada gambar 3.1 menunjukkan blok diagram dari penelitian yang akan dilakukan pada sistem rancang bangun turbin ulir.

\section{h. Alat dan Bahan Penelitian}

Alat-alat dan bahan-bahan yang digunakan dalam penelitian ini adalah meliputi:

1. Pipa galvanis

2. Plat baja

3. Poros

4. Bantalan (Bearing)

5. Puli (Pulley)

6. Sabuk $(V$-Belt $)$

7. Mesin pemotong baja (gergaji besi)
8. Mesin las

9. Mesin bubut

10. Alat bantu perbengkelan, seperti: palu, tang kunci pas, kunci inggris, obeng dan lain sebagainya.

11. Flowmeter untuk mengukur kecepatan air

12. Tachometer untuk mengukur kecepatan putaran turbin

13. Multimeter untuk mengukur arus dan tegangan yang dihasilkan

14. Lampu listrik ukuran daya 3,5 watt untuk pembebanan

15. Kabel listrik

\section{i. Prosedur Penelitian}

Pada penelitian ini terdiri dari beberapa tahapan, sebagai langkah awal dilakukan studi literatur maupun survey lapangan, selanjutnya dilakukan perancangan desain seluruh turbin (panjang, diameter dalam, head, debit dan luas saluran) dengan menggunakan vernier calliper (jangka sorong), kemudian dihitung dimensi turbin. Setelah desain sesuai selanjutnya desain tersebut digambar menggunakan software Autocad dan pembuatan bentuk turbin. Setelah turbin dibuat dan dipasang tahapan selanjutnya adalah menguji setiap model turbin kembali sampai diperoleh hasil yang sesuai.

Langkah selanjutnya adalah pembuatan pembangkit daya listrik dengan menggunakan GENERATOR, pembuatan pembangkitan daya listrik dilakukan untuk melihat hasil uji daya optimum setelah masuk ke rangkaian listrik. Pengujian rangkaian menggunakan beberapa alat ukur diantaranya Flowmeter, Tachometer dan Multimeter yang digunakan untuk mengukur arus dan tegangan ke konsumen yang hasilnya dapat dilihat secara digital berupa angka. Jika hasil pengukuran yang terbaca oleh display sudah identik dengan multimeter digital, maka rangkaian listrik dan turbin sudah sesuai.

Berikutnya adalah pendesainan rangkaian listrik pada papan panel rangkaian dengan 3 buah lampu, rangkaian yang dibuat digunakan untuk menampilkan hasil pembangkitan arus listrik yang dihasilkan dari generator tersebut maupun pembangkitan arus lainnya serta menampilkan nyala lampu yang akan digunakan untuk memonitoring pembebanan dan kerja dari generator dan 
turbin. Rangkaian listrik yang dibuat tentu saja harus dapat mengalirkan arus searah kurang lebih mendekati dari hasil yang sebenarnya. Arus listrik ini juga akan disertai tegangan yang akan menampilkan pemakaian beban oleh lampu. Setelah rangkaian listrik selesai dibuat kemudian dilakukan instalasi dan penyambungan dengan dinamo generator menggunakan kabel agar tidak terjadi kesalahan saat lampu dihidupkan, sebagai pengatur tegangan digunakan penyearah arus dan lampu sebagai beban.

Setelah rangkaian listrik dapat berjalan dengan baik maka dilanjutkan dengan perakitan seluruh komponen ke dalam chassis turbin yang digabungkan dengan gearbox dan sistem pemindah tenaga. Langkah selanjutnya adalah pemasangan puli (Pulley) pada V-Belt yang dilakukan untuk uji coba mensinkronisasikan putaran yang dalam keadaan asli menggunakan generator, beban lampu, puli (Pulley) dan V-belt.

\section{HASIL PENELITIAN DAN ANALISA PEMBAHASAN}

Pada bab empat ini akan dibahas hasil dan analisa dari pengujian arus, tegangan dan frekuensi dari sistem screw turbin ini. Pengukuran ketiga jenis daya menggunakan sistem pengambilan data melalui alat ukur.

Tabel 2 Data Daya, Kecepatan putaran turbin dan generator untuk $\Lambda=2$ Ro.

\begin{tabular}{|c|c|c|c|c|c|c|}
\hline $\begin{array}{c}\text { Sudut } \\
(\mathbf{(})\end{array}$ & $\begin{array}{c}\text { Jumlah } \\
\text { Lampu }\end{array}$ & $\begin{array}{c}\mathbf{V}_{\mathbf{L}} \\
\text { (Volt) }\end{array}$ & $\begin{array}{c}\mathbf{I}_{\mathbf{L}} \\
\text { (Amp.) }\end{array}$ & $\begin{array}{c}\mathbf{P}_{\mathbf{g}} \\
\text { (Watt) }\end{array}$ & $\begin{array}{c}\mathbf{N}_{\mathbf{t}} \\
(\mathbf{r p m})\end{array}$ & $\begin{array}{c}\mathbf{\eta}_{\mathbf{g}} \\
(\mathbf{r p m})\end{array}$ \\
\hline 25 & 0 & 4,6 & 1,3 & 5,98 & 315 & 615 \\
\cline { 2 - 7 } & 1 & 3,7 & 1,1 & 4,07 & 310 & 605 \\
\cline { 2 - 7 } & 2 & 2,6 & 0,9 & 2,34 & 306 & 590 \\
\cline { 2 - 7 } & 3 & 1,6 & 0,8 & 1,28 & 303 & 575 \\
\hline 30 & 0 & 4,1 & 1,3 & 5,33 & 295 & 595 \\
\cline { 2 - 7 } & 1 & 3,2 & 1,2 & 3,84 & 290 & 580 \\
\cline { 2 - 7 } & 2 & 2,4 & 0,9 & 2,16 & 288 & 560 \\
\cline { 2 - 7 } & 3 & 1,5 & 0,7 & 1,05 & 285 & 555 \\
\hline 35 & 0 & 3,7 & 1,3 & 4,81 & 257 & 570 \\
\cline { 2 - 7 } & 1 & 2,8 & 1,1 & 3,08 & 246 & 560 \\
\cline { 2 - 7 } & 2 & 1,9 & 0,8 & 1,52 & 229 & 540 \\
\cline { 2 - 7 } & 3 & 1,1 & 0,6 & 0,66 & 208 & 535 \\
\hline
\end{tabular}

Data Daya, Kecepatan putaran turbin dan generator Untuk $\Lambda=2$ Ro

Dimana:

$\mathrm{V}_{\mathrm{L}}=$ tegangan listrik (Volt)

$\mathrm{I}_{\mathrm{L}}=\operatorname{arus~listrik}$ (Ampere)

$\mathrm{N}_{\mathrm{t}}=$ kecepatan putaran turbin (rpm)

$\mathrm{N}_{\mathrm{g}}=$ kecepatan putaran generator $(\mathrm{rpm})$

Analisa perhitungan data hasil pengujian di atas dapat ditampilkan ke dalam bentuk grafik untuk mengetahui fenomena yang terjadi pada daya generator dan kemiringan poros turbin terhadap jumlah beban lampu yang digunakan yaitu sebagai berikut:

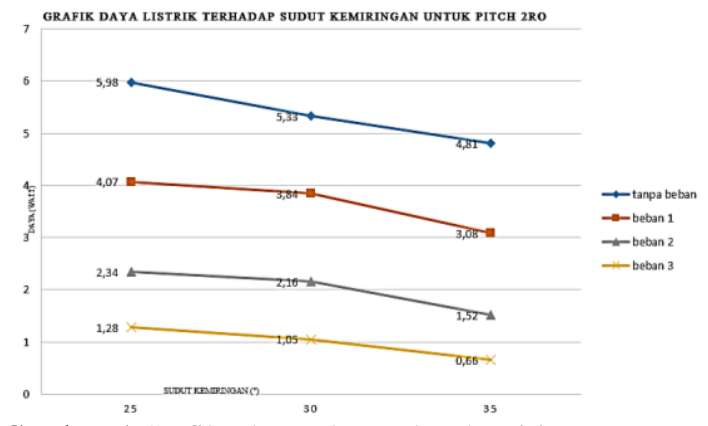

Gambar 5 Grafik daya dan sudut kemiringan poros turbin terhadap jumlah beban lampu pada $\Lambda=2 R_{0}$.

Grafik di atas menunjukan bahwa unjuk kerja terbaik model turbin ulir yang menghasilkan daya output generator paling besar terjadi pada sudut kemiringan $30^{\circ}$. Dari sudut $25^{\circ}-30^{\circ}$ daya generator naik dan turun setelah sudut kemiringan lebih besar dari $30^{\circ}\left(\theta>30^{\circ}\right)$.

Tabel 3 Data Daya, Kecepatan putaran turbin dan generator untuk $\Lambda=1,2$ Ro.

\begin{tabular}{|c|c|c|c|c|c|c|}
\hline $\begin{array}{c}\text { Sudut } \\
\left.\mathbf{(}^{(}\right)\end{array}$ & $\begin{array}{c}\text { Jumlah } \\
\text { lampu }\end{array}$ & $\begin{array}{c}\mathbf{V}_{\mathbf{L}} \\
\text { (Volt) }\end{array}$ & $\begin{array}{c}\mathrm{I}_{\mathbf{L}} \\
(\text { Amp.) }\end{array}$ & $\begin{array}{c}\mathbf{P}_{\mathbf{g}} \\
(\mathbf{W a t t})\end{array}$ & $\begin{array}{c}\mathbf{N}_{\mathbf{t}} \\
(\mathbf{r p m})\end{array}$ & $\begin{array}{c}\mathbf{N}_{\mathbf{g}} \\
(\mathbf{r p m})\end{array}$ \\
\hline 25 & 0 & 3,8 & 1,4 & 5,32 & 352 & 725 \\
\cline { 2 - 7 } & 1 & 3,1 & 1,1 & 3,41 & 344 & 665 \\
\cline { 2 - 7 } & 2 & 2,3 & 0,9 & 2,07 & 331 & 540 \\
\cline { 2 - 7 } & 3 & 1,1 & 0,6 & 0,66 & 323 & 525 \\
\hline 30 & 0 & 4,7 & 1,4 & 6,58 & 387 & 785 \\
\cline { 2 - 7 } & 1 & 3,9 & 1,2 & 4,68 & 382 & 770 \\
\cline { 2 - 7 } & 2 & 3,1 & 1 & 3,1 & 367 & 765 \\
\cline { 2 - 7 } & 3 & 2,6 & 0,7 & 1,82 & 356 & 745 \\
\hline 35 & 0 & 4,2 & 1,4 & 5,88 & 349 & 690 \\
\cline { 2 - 7 } & 1 & 3,5 & 1,1 & 3,85 & 329 & 585 \\
\cline { 2 - 7 } & 2 & 2,9 & 0,8 & 2,32 & 318 & 505 \\
\cline { 2 - 7 } & 3 & 1,4 & 0,6 & 0,84 & 303 & 475 \\
\hline
\end{tabular}

Analisa perhitungan data hasil pengujian di atas dapat ditampilkan ke dalam bentuk grafik untuk mengetahui fenomena yang terjadi pada daya generator dan kemiringan poros turbin terhadap jumlah beban lampu yang digunakan pada $\Lambda=$ $1.2 \mathrm{R}_{0}$ yaitu sebagai berikut: 


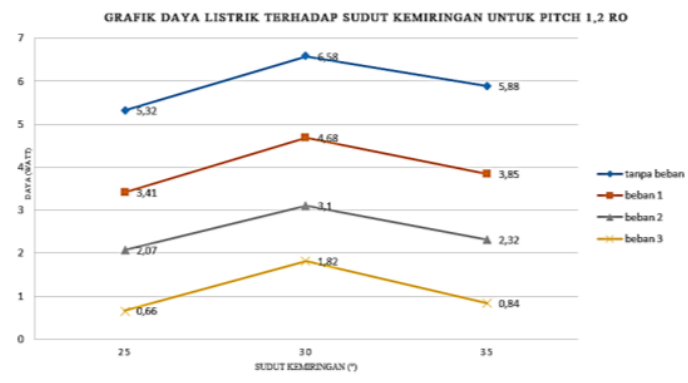

Gambar 6 Grafik daya dan sudut kemiringan poros turbin terhadap jumlah beban lampu pada $\Lambda=$ $1,2 \mathrm{R}_{0}$.

Grafik di atas menunjukkan bahwa unjuk kerja terbaik model turbin ulir yang menghasilkan daya output generator paling besar terjadi pada sudut kemiringan $30^{\circ}$ juga. Dari perhitungan data hasil pengujian di atas dapat dianalisa bahwa putaran di poros generator terhadap jumlah beban lampu, dimana semakin besar pembebanan lampu yang diberikan, maka putaran poros generator juga akan semakin berkurang. Dengan berkurangnya putaran poros generator maka tegangan yang dihasilkan juga semakin berkurang sesuai penambahan beban lampu. Hal ini dapat diilustrasikan pada tenaga yang digunakan untuk memutar rotor adalah roda sepeda. Jika roda berputar, maka kumparan atau magnet ikut berputar.

Analisa daya dan efisiensi hasil pengujian di setiap penambahan beban lampu pada masing-masing pitch terhadap sudut kemiringan poros.

Dari data yang diperoleh dari hasil pengujian di lapangan, dapat diketahui efisiensi generator di setiap penambahan beban lampu pada masing-masing pitch dengan menggunakan persamaan yaitu:

$\eta=\frac{\text { daya output }}{\text { daya input }} \times 100 \%$

atau $\eta_{g}=\frac{P_{g}}{P_{t}} \times 100 \%$

Data daya $(\mathrm{Pg})$ dan efisiensi $(\eta \mathrm{g})$ generator di setiap penambahan beban lampu pada masing-masing pitch terhadap sudut kemiringan poros dapat dilihat pada Tabel 4 berikut ini:
Tabel 4 Data daya dan efisiensi generator hasil pengujian tanpa lampu.

\begin{tabular}{|c|c|c|c|c|c|c|}
\hline No & Pitch & $\begin{array}{l}\text { Sudut } \\
\left({ }^{\circ}\right)\end{array}$ & $\begin{array}{c}\mathbf{P}_{\mathbf{g}} \\
(\mathrm{W})\end{array}$ & $\begin{array}{c}\mathbf{P}_{\mathbf{t}} \\
(\mathrm{W})\end{array}$ & $\begin{array}{c}\mathrm{T} \\
(\mathrm{Nm})\end{array}$ & $\begin{array}{c}\eta_{\mathrm{g}} \\
(\%)\end{array}$ \\
\hline 1 & \multirow[t]{3}{*}{2 Ro } & 25 & 5,98 & 0,00 & 0,00 & \\
\hline 2 & & 30 & 5,33 & 0,00 & 0,00 & \\
\hline 3 & & 35 & 4,81 & 0,00 & 0,00 & \\
\hline 4 & \multirow[t]{3}{*}{$\begin{array}{l}1,2 \\
\text { Ro }\end{array}$} & 25 & 5,32 & 0,00 & 0,00 & \\
\hline 5 & & 30 & 6,58 & 0,00 & 0,00 & \\
\hline 6 & & 35 & 5,88 & 0,00 & 0,00 & \\
\hline
\end{tabular}

Analisa perhitungan data hasil pengujian di atas dapat ditampilkan ke dalam bentuk grafik untuk mengetahui fenomena yang terjadi pada daya dan efisiensi hasil pengujian pada masing-masing pitch terhadap sudut kemiringan poros turbin pada Gambar 4.3 dan untuk data daya turbin dapat dilihat pada lampiran.

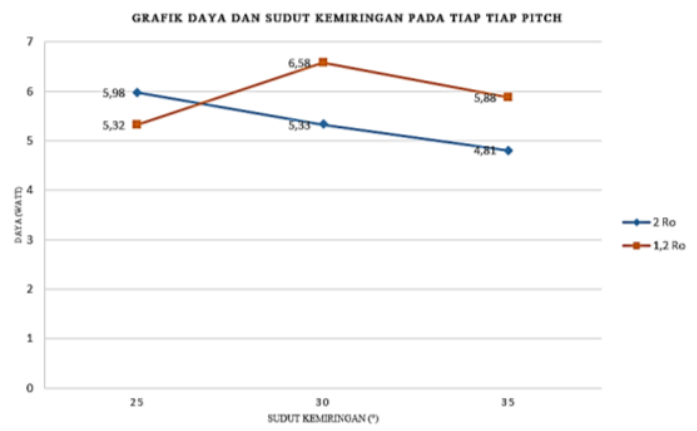

Gambar 7 Grafik daya dan efisiensi pada masingmasing pitch terhadap sudut kemiringan poros tanpa lampu.

Dari grafik di atas dapat dianalisa bahwa pada pitch $1,2 \mathrm{R}_{0}$ menunjukkan daya tertinggi sebesar 6,58 watt pada sudut kemiringan poros $30^{\circ}$ dan efisiensi tertinggi pada pitch $1,2 R_{0}$ dengan sudut kemiringan poros $30^{\circ}$ yaitu sebesar $84 \%$, dimana perbandingan pengukuran daya generator dan daya turbin kecil, sehingga didapatkan nilai efisiensi yang besar.

Tabel 5. Data daya dan efisiensi generator hasil pengujian satu lampu.

\begin{tabular}{|c|c|c|c|c|c|c|}
\hline No & Pitch & $\begin{array}{c}\text { Sudut } \\
\left({ }^{\circ}\right)\end{array}$ & $\begin{array}{c}P_{g} \\
(W)\end{array}$ & $\begin{array}{c}P_{t} \\
(W)\end{array}$ & $\begin{array}{c}\mathrm{T} \\
(\mathrm{Nm})\end{array}$ & $\begin{array}{c}\eta_{\mathrm{g}} \\
(\%)\end{array}$ \\
\hline 1 & \multirow[t]{3}{*}{2 Ro } & 25 & 4,07 & 27,6204 & 0,9810 & 14,14735 \\
\hline 2 & & 30 & 3,84 & 29,4686 & 0,9810 & 13,03081 \\
\hline 3 & & 35 & 3,08 & 35,9373 & 0,9810 & 8,57048 \\
\hline 4 & \multirow[t]{3}{*}{$\begin{array}{l}1,2 \\
\text { Ro }\end{array}$} & 25 & 3,41 & 22,6918 & 0,9810 & 15,02745 \\
\hline 5 & & 30 & 4,68 & 23,9240 & 0,9810 & 19,56194 \\
\hline 6 & & 35 & 3,85 & 24,0267 & 0,9810 & 16,02384 \\
\hline
\end{tabular}


Grafik dari data di atas dapat dilihat pada gambar 8 di bawah ini.

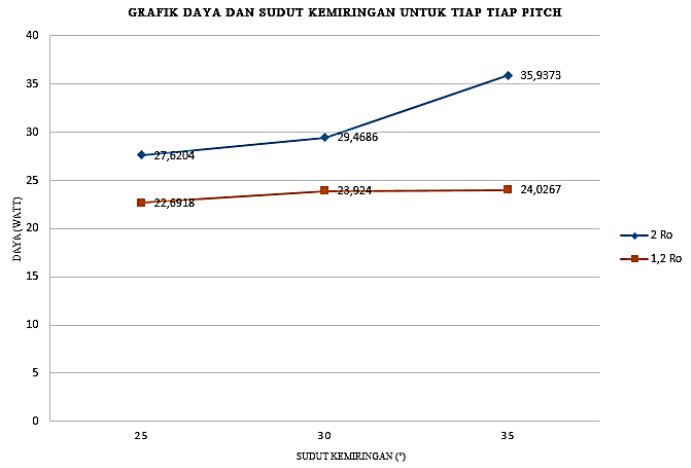

Gambar 8 Grafik daya dan efisiensi pada masing-masing pitch terhadap sudut kemiringan poros dengan satu lampu.

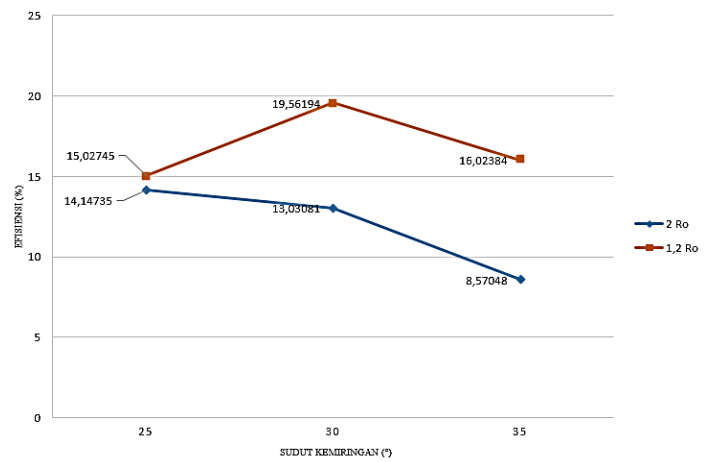

Gambar 9 Grafik daya dan efisiensi pada masingmasing pitch terhadap sudut kemiringan poros dengan satu lampu.

Dari grafik di atas menunjukan bahwa pada pitch $2 \mathrm{R}_{0}$ memiliki daya generator dan efisiensi tertinggi pada sudut $35^{\circ}$, dengan daya generator sebesar 4,68 watt dan efisiensi sebesar 19,56194\%.

Tabel 6 Data daya dan efisiensi generator hasil pengujian dua lampu.

\begin{tabular}{|c|c|c|c|c|c|c|}
\hline No & Pitch & $\begin{array}{c}\text { Sudut } \\
\left({ }^{\circ}\right)\end{array}$ & $\begin{array}{l}\mathbf{P}_{\mathbf{g}} \\
(\mathrm{W})\end{array}$ & $\begin{array}{c}\mathbf{P}_{\mathbf{t}} \\
(\mathrm{W})\end{array}$ & $\begin{array}{c}\mathrm{T} \\
(\mathrm{Nm})\end{array}$ & $\begin{array}{c}\eta_{\mathrm{g}} \\
(\%)\end{array}$ \\
\hline 1 & \multirow[t]{3}{*}{2 Ro } & 25 & 2,34 & 54,0086 & 1,9620 & 4,33264 \\
\hline 2 & & 30 & 2,16 & 56,8836 & 1,9620 & 3,79722 \\
\hline 3 & & 35 & 1,52 & 65,5086 & 1,9620 & 2,32030 \\
\hline 4 & \multirow[t]{3}{*}{$\begin{array}{l}1,2 \\
\text { Ro }\end{array}$} & 25 & 2,07 & 44,1515 & 1,9620 & 4,68840 \\
\hline 5 & & 30 & 3,1 & 47,6426 & 1,9620 & 6,50678 \\
\hline 6 & & 35 & 2,32 & 42,9194 & 1,9620 & 5,40548 \\
\hline
\end{tabular}

Grafik dari data di atas dapat dilihat pada Gambar 10 di bawah ini.

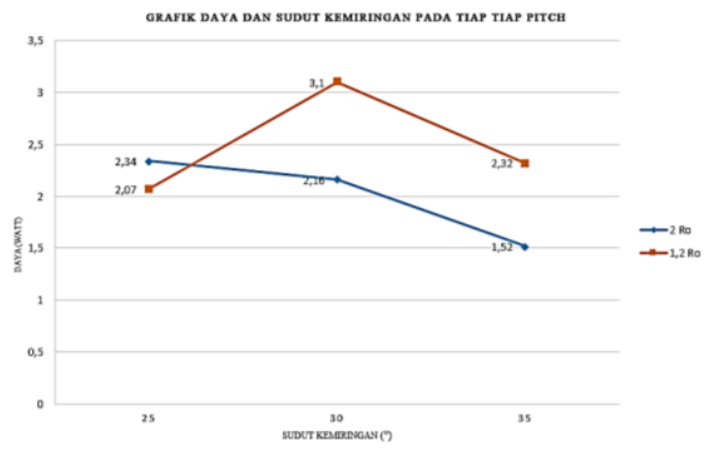

Gambar 10 Grafik daya dan efisiensi pada masingmasing pitch terhadap sudut kemiringan poros dengan dua lampu.

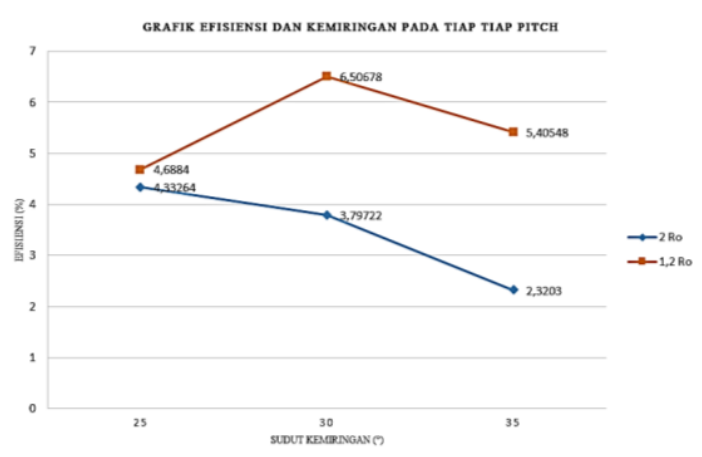

Gambar 11 Grafik daya dan efisiensi pada masingmasing pitch terhadap sudut kemiringan poros dengan dua lampu.

Dari grafik di atas menunjukan bahwa pada pitch $1,2 \mathrm{R}_{0}$ memiliki daya generator tertinggi pada sudut $30^{\circ}$, dimana masing- masing daya generator sebesar 3,1 watt serta efisiensi sebesar 6,50678\%.Dari grafik efisiensi dan sudut kemiringan tiap-tiap pitch, terlihat bahwa pada pitch $1,2 R_{0}$ menunjukan efisiensi tertinggi pada sudut $30^{\circ}$. Hal ini sama dengan hasil ukur tanpa lampu. Jadi hasil pengukuran di atas masih terdapat kesalahan-kesalahan pengukuran pada saat pengambilan data di lapangan.

Tabel 7 Data daya dan efisiensi generator hasil pengujian tiga lampu.

\begin{tabular}{|c|c|c|c|c|c|c|}
\hline No & Pitch & $\begin{array}{l}\text { Sudut } \\
\left({ }^{\circ}\right)\end{array}$ & $\begin{array}{c}P_{g_{R}} \\
\text { (W) }\end{array}$ & $\begin{array}{c}P_{t} \\
(W)\end{array}$ & $\begin{array}{c}\mathrm{T} \\
(\mathrm{Nm})\end{array}$ & $\begin{array}{c}\eta_{g} \\
(\%)\end{array}$ \\
\hline 1 & \multirow[t]{3}{*}{2 Ro } & 25 & 1,28 & 81,3210 & 2,9430 & 1,57400 \\
\hline 2 & & 30 & 1,05 & 90,2540 & 2,9430 & 1,16338 \\
\hline 3 & & 35 & 0,66 & 101,9593 & 2,9430 & 0,64731 \\
\hline 4 & \multirow[t]{3}{*}{ 1,2 Ro } & 25 & 0,66 & 63,1470 & 2,9430 & 1,04518 \\
\hline 5 & & 30 & 1,82 & 71,1559 & 2,9430 & 2,55776 \\
\hline 6 & & 35 & 0,84 & 63,7630 & 2,9430 & 1,31737 \\
\hline
\end{tabular}

Grafik dari data di atas dapat dilihat pada Gambar 12 di bawah ini. 


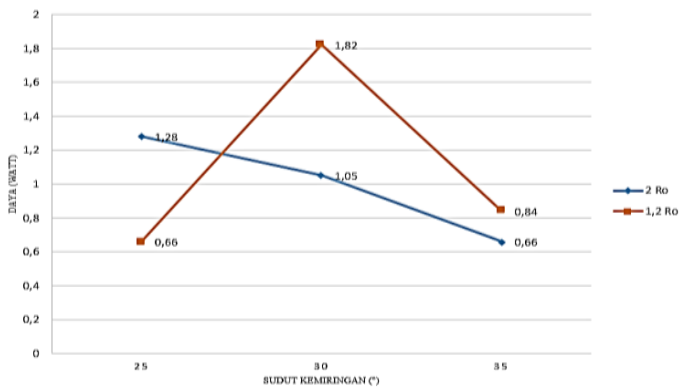

Gambar 13 Grafik daya dan efisiensi pada masingmasing pitch terhadap sudut kemiringan poros dengan tiga lampu.

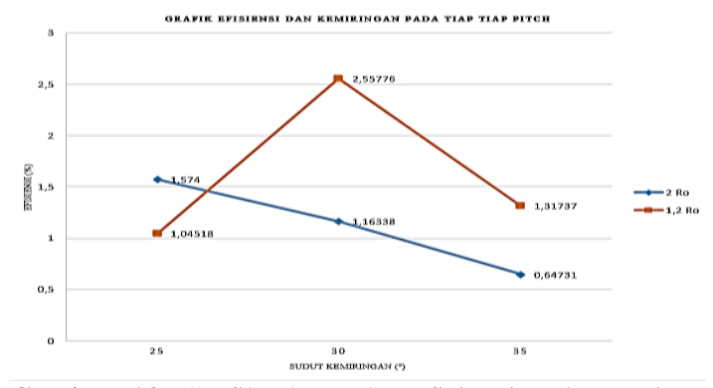

Gambar 13 Grafik daya dan efisiensi pada masingmasing pitch terhadap sudut kemiringan poros dengan tiga lampu.

Dari grafik di atas menunjukan bahwa pada pitch $1,2 \mathrm{R}_{0}$ memiliki daya generator dan efisiensi tertinggi pada sudut $30^{\circ}$, dengan daya generator sebesar 1,82 watt dan efisiensi sebesar 2,55776\%.

\section{KESIMPULAN}

Berdasarkan hasil penelitian, maka dapat disimpulkan hal-hal sebagai berikut:

1. Pada setiap penambahan variasi kemiringan poros, masing-masing model turbin ulir cenderung menunjukkan karakteristik yang sama yaitu mengalami peningkatan daya dari kemiringan poros $25^{\circ}$ hingga $30^{\circ}$, namun daya yang dihasilkan kemudian menurun dari kemiringan poros $30^{\circ}$ hingga $35^{\circ}$. Daya dan Efisiensi tertinggi yang diperoleh dari masing-masing jarak pitch model turbin ulir dua blade adalah pada kemiringan poros $30^{\circ}$. Semakin besar kecepatan putaran generator, maka semakin besar gaya yang bekerja pada sabuk-puli. Begitu juga dengan torsi (momen puntir), semakin besar daya generator, maka torsi yang ditimbulkan juga semakin besar.

2. Pada pengujian berbeban, secara umum model turbin ulir dengan jarak pitch 1,2Ro memberikan daya yang lebih tinggi dibandingkan dengan model turbin ulir dengan jarak pitch 2 Ro dengan daya generator sebesar 4,68 watt dan efisiensi sebesar 19,56194\%. Pitch $1,2 \mathrm{R}_{0}$ menunjukkan daya tertinggi sebesar 6,58 watt pada sudut kemiringan poros $30^{\circ}$ dan efisiensi tertinggi pada pitch $1,2 \mathrm{R}_{0}$ dengan sudut kemiringan poros $30^{\circ}$ yaitu sebesar $84 \%$ tanpa pengujian beban. Efisiensi generator adalah hasil pembagian dari daya generator dan daya turbin yang didapat dari hasil pengukuran. Pada pengujian model turbin ulir, semakin besar pembebanan lampu yang diberikan, maka putaran generator juga akan semakin berkurang.

\section{DAFTAR PUSTAKA}

Alois, Koller. 1986. Rangkaian Arus Listrik. Jakarta: PT Intermasa, 2016.

Bard. N. 2007. River Dart Country Park Archimedes Screw System Performance Assessment. (Artikel). Mannpower Consulting Ltd.

Daryanto. Teknik Pengerjaan Listrik. Ed. 1 Cet. 3, Jakarta: Bumi Aksara, 2006.

ESHA. 2005. State of the Art of Small Hydropower in EU-25. Brussels: European Small Hydropower Association.

Haryono, A., Gunawan, S., dan Hansen, M. 2007. Potensi Tenaga Pasang Surut sebagai Alternatif Pembangkit Tenaga Listrik Menggunakan Model Waduk Penampung Air di Bengkulu. Jurnal Sains dan Tenologi Indonesia BPPT/ANY, 5 (5).

Kadir, Abdul. 1996. Pembangkit Tenaga Listrik. Jakarta: Penerbit Universitas Indonesia (UI-Press).

Mahmood Nahvi dan Joseph A. Edminister. 2004. Rangkaian Listrik. Jakarta: Penerbit Erlangga

Pudjanarso, Astu. Djati Nursuhud. Mesin Konversi Energi. Ed. III, Yogyakarta: Andi

Satriyo, Puguh Adi, ST. Pemanfaatan Pembangkit Listrik Tenaga Mikrohidro Untuk Daerah Terpencil. Puslitbang Iptekhan Balitbang Dephan. 